\title{
Relevansi Hadis Larangan Marah Dengan Kesehatan Mental
}

\author{
Hammydiati Azifa Lazuardini I \\ Pascasarjana UIN Sunan Kalijaga Yogyakarta \\ hammydiatiazifa@gmail.com
}

DOI: $10.29240 /$ alquds.v3i1.610

Submitted: 2018-11-27| Revised: 2019-04-02|Accepted: 2019-05-01

\begin{abstract}
This paper aims to find out the meaning contained in the Angry Hadith which is examined from the psychological aspect. This is based on a phenomenon that occurs where humans are often excessive in anger when facing one thing. Even though the Prophet SAW had said and called on his people not to be angry or emotional. Because angry behavior is not just the teachings conveyed, but the impact of anger will be very detrimental and affect the mental, psychological and neurological conditions. The research is qualitative research with analytical literature study method. The relevance of the hadith prohibits anger with mental health, which is seen from its neuropsychological effects, namely tense the nerves of the body, turbulence of blood and the tendency of an unstable brain. In addition, angry behavior is not only in the form of increasing psychological tension but also the emergence of negative behavior. Then anger can be minimized not only through psychological therapy but also spiritually. From the intervention in this study in the aspect of Islam, that this hadith can be used as a therapy or balancer in daily life, especially in anger, which can then be conveyed through da'wah pulpits, especially this hadith is included in the hadith so that it can become the basis law (hadith reference). So that from this reference, it is expected that humans can be better able to maintain behavior in their lives, be able to filter things well and no longer be easily provoked by emotions.
\end{abstract}

Keywords: Hadith of Angry Prohibition, Angry Impacts, Mental Health, Cognitive Psychology

\begin{abstract}
Abstrak. Tulisan ini bertujuan untuk mengetahui makna yang terkandung dalam Hadis Marah yang dikaji dari aspek psikologis. Hal inididasarkanpadafenomena yang terjadi di mana manusia sering berlebihan dalam marah ketika menghadapi satu hal. Padahal Nabi SAW sudah bersabda dan menyerukan kepada umatnya untuk tidak marah atau emosi.Sebab perilaku marah tersebut bukan hanya sekedar ajaran yang disampaikan, melainkan dampak dari marah itu akan sangat merugikan dan berpengaruh pada kondisi mental, psikologis dan neurologis. Adapun penelitian ini merupakan penelitian kualitatif dengan metode studi pustaka analisa. Relevansi hadis larangan marah dengan kesehatan mental yakni dilihat dari dampaknya secara neuropsikologi yakni menegangnya saraf-
\end{abstract}


saraf tubuh, bergejolaknya darah dan kecenderungan otak yang tidak stabil. Selain itu perilaku marah tidak hanya dalam bentuk secara meningginya tensi psikologis tetapi juga munculnya perilaku negatif. Kemudian marah bisa diminimalisir tidak hanya melalui terapi psikologis tetapi juga secara spiritual. Dari intervensi dalam penelitian ini dalam aspek Islam yakni bahwa hadis ini bisa dijadikan sebagai terapi atau penyeimbang dalam kehidupan sehari-hari pada khususnya dalam keadaan marah, yang kemudian dapat disampaikan melalui mimbar-mimbar dakwah terlebih hadis ini termasuk ke dalam hadis shahih sehingga bisa menjadi dasar hukum (referensi hadis). Ehingga dari adanya referensi ini diharapkan manusia bisa lebih mampu untuk menjaga perilaku dalam hidupnya, mampu menyaring sesuatu dengan baik dan tiidak lagi untuk mudah terpancing emosi.

Kata Kunci: Hadis Larangan Marah, Dampak Marah, Kesehatan Mental, Psikologi Kognitif

\section{Pendahuluan}

Islam diturunkan sebagai panduan bagi manusia dalam menjalani hidupnya. Akal tidak sepenuhnya bisa memilah baik dan buruk. Namun demikian kenyataannya seringkali agama menjadi pemicu kemarahan dari satu golongan kepada golongan lain. Jargon-jargon agama menjadi justifikasi bagi sikap-sikap yang sebenarnya luapan kemarahan. Oleh sebab itu, dalam memahami ajaran agama, yang lebih penting adalah manusianya terlebih dahulu. Apakah ia sudah terbebas dari ambisi duniawi, dari interes politik dan agenda lainnya. Jika menurut Sigmund Freud id adalah emosi manusia yang berisfat bawaaan, demikian juga menurut al-Ghazali, maka pertanyaannya bagaimana manusia mengendalikan emosi agar ia bisa mengendalikan kecenderungannya dan tidak bersikap berlebihan.

Adanya perilaku manusia yang tidak mampu mengendalikan emosi dan rasionya, maka secara utuh dia telah lemah dalam mengendalikan dirinya sendiri. Oleh karenanya perilaku tersebut tidak hanya membahayakan diri sendiri saja, tetapi juga dapat membahayakan orang lain. ${ }^{1}$ Marah merupakan sebuah perasaan emosi yang familiar dalam sehari-hari. Biasanya ketika seseorang marah akan digambarkan dengan perilaku diam atau bahkan menarik diri, juga bisa sampai pada hal yang dapat menciderai diri sendiri aatau orang lain. Latar belakang yang menjadi pemicu pun beragam, mulai dari hal yang sepele sampai hal yang serius. ${ }^{2}$

Rita Susanti (2014) dalam penelitiannya menyatakan bahwa penyebab utama dari emosi marah adalah prasaan yang terluka persepsi terhadap ketidakadilan, dan adanya perilaku yang tidak diharapkan. Perasaan tersebut dirasakan ketika terjadi hal yang tidak sesuai atau negatif. Oleh karenanya marah

${ }^{1}$ S. M Lari, Psikologi Islam (Bandung: Pustaka Hidayah, 1995), 114.

${ }^{2}$ M. Darwis Hude, Emosi (Jakarta: Penerbit Erlangga, 2006), 162. 
lebih disebabkan oleh aspek afektif dari pada kognitif. ${ }^{3}$ Selain itu, Moch Sya'roni Hasan (2017) yang menulis mengenai "Manajemen Marah dan Urgensinya dalam pendidikan" menyebutkan mengenai definisi marah, dampak negatif dan cara mengelola emosi yang dikaji berdasarkan ayat Alquran dan berdasarkan pada aspek batiniahnya. Dalam tulisannya disebutkan bahwa marah lebih didefinisikan perubahan pada perilaku seseorang kepada hal yang bersifat negatif, misalnya mengamuk, benci bahkan patologois. Hal tersebut hanya bisa dicegah dengan perilaku yang positif, seperti mengendalikannya, memaafkan dan selalu berdzikir. ${ }^{4}$

Nyatanya sikap marah akan membuat manusia menjadi berbeda dari jati dirinya, misalnya saja dari yang baik berubah menjadi jahat. Bahkan mampu menutup rasio mereka pada sesuatu yang baik. ${ }^{5}$ Salah satu sebab terbesar dari adanya kemarahan adalah karena suatu hal yang tidak tersampaikan dengan baik atau tidak sesuai dengan tujuan yang diharapkan. Hal tersebutlah yang juga mendorong kemarahan tersebut semakin meluap. ${ }^{6}$ Selain itu, faktor yang menyebabkan seseorang marah seperti yang dituliskan oleh Safiruddin Al-Baqi (2015) antara lain selain faktor budaya, juga disebabkan oleh pola asuh yang diterima anak dari orang tuanya, perbedaan jender dan sebagainya. ${ }^{7}$ Penelitian dari Nandhini H. Anggarasari, dkk (2014) yang meneliti mengenai "Terapi Tawa Untuk Mengurangi Emosi Marah Pada Caregiver Lansia" mnejelaskan mengenai manfaat dari terapi tawa yang dilakukan. Dari penelitian ini menghasilkan bahwa terapi tawa bisa menimbulkan efek tenang dan bugar. ${ }^{8}$

Dari beberapa penelitian terdahulu yang telah dipaparkan di atas, kebanyakan hanya meneliti mengenai emosi marah dari aspek Alquran saja, kemudian hal-hal yang dapat menyebabkan marah, efek yang ditimbulkan dari marah, serta beberapa hal atau kegiatan yang bisa dijadikan sebagai terapi marah. Oleh karenanya peneliti tertarik untuk mengkaji lebih lanjut mengenai hadis marah dan ke-shahih-annya yang menggunakan metode kritik sanad, dan juga relevansi dari hadis larangan marah dengan kesehatan mental.

${ }^{3}$ Rita Susanti, dkk, "Perasaan Marah Membuat Terluka" 10 No.2, Jurnal Psikologi (December 2014).

${ }^{4}$ Moch. Sya'roni Hasan, "Manajemen Marah Dan Urgensinya Dalam Pendidikan” 1 No.2, Al-Idaroh (September 2017).

${ }^{5}$ M. Asy-Syahawi, Saat-Saat Rasulullah Marah (Jakarta: Pustaka Azzam, 2005), 22.

'Ibid., 104.

${ }^{7}$ Safiruddin Al- Baqi, "Ekspresi Emosi Marah" 23, no. Fakultas Psikologi Universitas Gadjah Mada, Buletin Psikologi (June 2015).

${ }^{8}$ Fuad Nashori Nandhini H. Anggarasari RA Retno Kumolohadi, "Terapi Tawa Untuk Mengurangi Emosi Marah Pada Caregiver Lansia” 6, No. 1, Jurnal Intervensi Psikologi (2014). 
Dalam penelitian ini penulis menggunakan metode kritik sanad-matan hadis. Sebenarnya kaedah atau rambu-rambu yang dipakai dalam penelitian hadis sebenarnya sudah sejak "lahirnya" hadis itu sendiri. Terbukti dengan upaya selektivitas yang dilakukan pra sahabat dalam menerima informasi tentang hadis yang tidak diterimanya secara langsung dari Nabi, yakni dengan mengecek ulang kebenaran berita langsung kepada Nabi. ${ }^{9}$ Atau dapat dikatakan bahwa metode tersebut untuk meneliti ulang mengenai kualitas hadis. Akan tetapi metode atau cara yang digunakan dalam penelitian ini menggunakan aplikasi Lidwa Pusaka Application dan juga Jawami' Al-Kalim Application. Metode ini merupakan suatu metode baru dalam mencari berbagai hadis klasik yang terangkum dalam satu aplikasi, dimana juga dicantumkan mengenai nomor hadiits, sanad, perawi hingga kualiatas hadis.Adapun tujuan dari penulisan ini adalah ingin meninjau ke-shahih-an dari hadis marah serta relevansinya dengan kesehatan mental yang ditinjau dari kajian psikologi.

\section{Pembahasan}

Menurut al-Ghazali, al-ghadhab merupakan bawaan manusia sejak lahir, yang bersifat givent. Ia berfungsi kedalam diri dan befungsi keluar. Al-Ghadhab dalam diri manusia seiring dengan kondisi biologis manusia dalam memenuhi kebutuhan biologisnya, seperti saat haus, lapar, dan kebutuhan biologis lainnya. Ghadhab mengawal manusia dalam memenuhi kebutuhan diri. Sedangkan fungsi keluar, ghadhab adalah fungsi pertahanan, ia seperti senjata yang berfungsi sebagai alat untuk melindungi diri dari segala hal yang membahayakan. Ghadhab pada dasarnya adalah potensi, namun demikian selayaknya senjata ghadhab perlu pengendalian. ${ }^{10}$

Al-Ghazali memakai istilah ifrath yaitu ketika seseorang dikuasai sifat ghadhab sampai tidak bisa dikendalikan oleh akal dan bimbingan agama. Sehingga seseorang tidak lagi mempunyai nurani, pertimbangan dan juga pemikiran. Sampai dia tidak lagi dapat memilih dan selau terdesak dengan amarahnya. Menurut al-Ghazali, faktor lingkungan, pergaulan, yang menganggap bahwa mengikuti amarah sebagai keberanian dan kejantanan bisa menyebabkan orang masuk pada kategori ifrath. Seperti orang mengatakan "saya tidak bisa memaafkan hal ini!", "saya tidak bisa tinggal diam". Pernyataan-pernyataan yang menunjukkan amarah dianggap sebagai satu-satunya indikator keberanian. Sehingga amarah membutakan hatinya dari segala nasihat.Tafrith, ketiadaan ghadhab dan ifrath, tidak terkendalinya ghadhab menurut al-Ghazali sama-sama

\footnotetext{
${ }^{9}$ Muhammad Alfatih Suryadilaga Suryadi, Metodologi Penelitian Hadits (Yogyakarta: TH Press, 2012), 100-101.

${ }^{10} \mathrm{Al}-$ Ghazali, Ibya Ulumidin Juz 3 (Indonesia: Maktabah Dar Iya Kutub al- Arabiyah, n.d.), 163.
} 
tercela, dan yang baik adalah i'tidal, yaitu kondisi ghadhab yang menunggu petunjuk akal dan bimbingan agama. Ghadhab akan bangkit ketika ia membutuhkan pertahanan diri. Dan ghadhab akan padam ketika situasi mengharuskan dia hilim atau mengampuni walaupun dia bisa menyalurkan ghadhab-nya. Itulah kondisi emosi terbaik dalam diri manusia, oleh al-Ghazali disebut $i$ 'tidal atau perkara yang sedang/ di tengah-tengah.

Menurut Edward E. Smit, Emosi merupakan naluriah dasar manusia. Emosi dapat mempengaruhi perhatian dan pemrosesan perseptual melalui cara yang berbeda. Sebagian besar penelitian yang mengkaji pengaruh emosi terhadap perhatian atau persepsi melaporkan adanya efek stimulus negatif, stimulus yang membangkitkan, atau stimulus yang terkait dengan ancaman, seringkali berupa perpaduan. ${ }^{11}$ Dalam pernyataan Edward tidak ada indikasi bahwa emosi dapat dikendalikan dapat dilatih dan fungsi positif negatifnya.

Terlepas dari hal itu, perilaku marah dapat disebabkan oleh beberapa faktor mendasar, seperti yang dikutip dalam HalloSehat.com, yakni: ${ }^{12}$ kurang tidur, depresi, gangguan cemas, dan harapan tidak sesuai kenyataan

\section{Hadis tentang larangan marah}

Salah satu sebab yang membuat banyak manusia takut dengan amarah adalah karena ia melahirkan kekuatan fisik yang luar biasa. Kekuatan tersebut bisa menguasai kalbu dan kepala kita. ${ }^{13}$ Karena pada dasarnya ketika seseorang mengalami kemarahan maka nalar yang ada akan hilang. Yang ada hanyalah nafsu menggebu-gebu yang merusak kesadaran. Saat amarah telah menguasai pikiran dan jiwa manusia, maka yang ada hanyalah munculnya sifat sombong dan berusaha untuk menjadi paling unggul dengan menjatuhkan lainnya. Maka sesungguhnya amarah tersebut telah membutakan hati dan pikiran manusia dan mencoba menjauhkan dari kenyataan yang ada. ${ }^{14}$

Kemudian ada hadis yang menjadi rujukan tentang larangan marah, yakni sebagai berikut:

${ }^{11}$ S. M. Edward E. Smit, Psikologi Kognitif: Pikiran Dan Otak (Yogyakarta: Pustaka Pelajar, 2014), 311.

${ }^{12}$ Widya Citra A, "4 Hal Yang Bisa Jadi Penyebab Anda Mudah Marah Sepanjang Hari," n.d., https://hellosehat.com/hidup-sehat/psikologi/4-penyebab-mudah-marah/.

${ }^{13}$ A. Qarni, Laa Taghdhab (Jangan Marah) (Jakarta: Al-Qalam, 2013), 22.

${ }^{14}$ S. M. Lari. Ibid., 114 


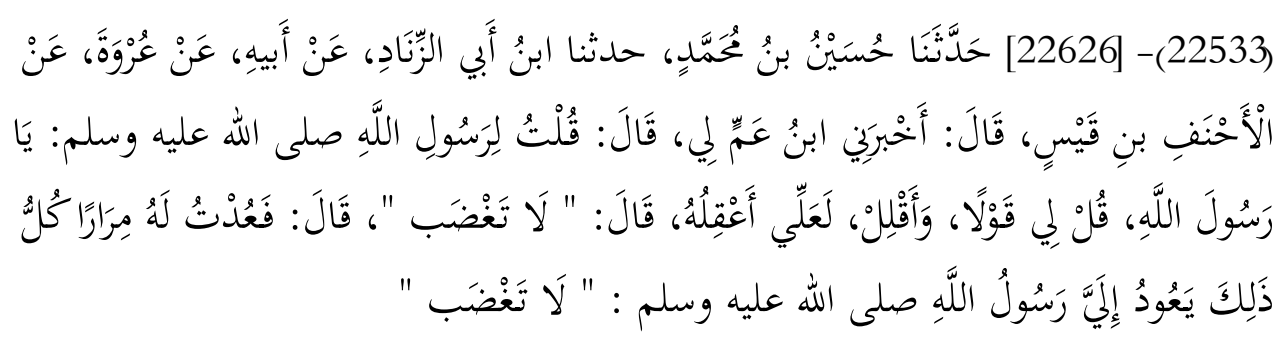

"Telah menceritakan kepada kami Husain bin Mubammad telah mengabarkan kepada kami Ibnu Abi Az. Zinad dari ayahnya dari Urwah dari Al-Abnaf bin Qais berkata: Telah mengabarkan kepadaku keponakanku, ia berkata: aku berkata kepada Rasulullah saw: Wahai Rasulullab! Sampaikanlah suatu perkataan padaku dan peringkaslah mudahmudahan aku memahaminya. Rasulullah saw bersabda: "Jangan marab!". Lalu aku mengulanginya berkali-kali, semuanya dibalas Rasullullab saw dengan sabda: "Jangan Marab!". (HR. Abmad) ${ }^{15}$

\section{Kajian Sanad Hadis}

Untuk mengetahui kualitas hadis ini, perlu dilakukan kritik terhadap sanadnya. Berikut uraian singkat biografi masing-masing perawi hadis ini:

Jariyah bin Qudamah. Nama lengkapnya adalah Jariyah bin Qudamah bin Zahir bin Hasin. Nasabnya adalah as-Sa'adi, at-Tamimi dan al-Basri. Kuniyahnya adalah Abu Abwab, Abu qudamah, dan Abu Yazid. Beliau tinggal di Basrah.

Adl Dlabhaak bin Qais. Nama lengkapnya adalah Adl Dlahhaak bin Qais bin Muawiyah bin Hushain. Merupakan Tabi'in kalangan tua. Kuniyahnya adalah Abu Bahar. Beliau tinggal di Basrah dan wafat di Kufah pada tahun $67 \mathrm{H}$.

Urwah bin Zubair. Nama lengkapnya adalah Urwah bin Zubair bin Awwam bin Khawailid bin As'ad bin 'Abdul Izzi bin Qu. Nasabnya adalah alFarisy, al-Asadi, dan al-Madani. Merupakan Tabi'in kalangan pertengahan. Kuniyahnya adalah Abu Abdullah. Beliau lahir di Madinah. Dan wafat pada tahun 93H. (Lidwa Pusaka)

Abdullah bin Drakwan.Nama lengkapnya adalah Abdullah bin Dzakwan Al-Farsyi (dalam Jwami al-kalim). Sedangkan di Lidwa pusaka nama lengkap beliau adalah Abdullah bin Dzakwan Abu Az-Zanad. Beliau lahir di Madinah pada tahun $64 \mathrm{H}$, dan wafat tahun $131 \mathrm{H}$ (menurut Jawami al-Kalim) atau $130 \mathrm{H}$ (menurut Lidwa Puasaka). Nasab beliau adalah al-Farsyi, Al-Madani. Kuniyah beliau adalah Abu Abdur Rahman.

\footnotetext{
${ }^{15}$ Aplikasi Hadits, Jawami’ Al-Kalim, n.d.
} 
Abdur Rabman bin Abi Abdullah. Nama lengkap beliau adalah Abdur Rahman bin Abdullah bin Dzakwan. Atau Abdur Rahman bin Abi Az Zanad Abdullahbin Dzakwan. Beliau termasuk Tabiut Tabi'in kalangan tua.bmeliau lahir di Madinah dan wafat pada tahun $174 \mathrm{H}$. Kuniyahnya adalah Abu Muhammad. Nasab beliau adalah Al-Farosyi, Al-Madani. (Jawami al-Kalim).

Husain bin Muhammad. Nama lengkapnya adalah Husain bin Muhammad bin Bahram bin Husain bin Muhammad at-Tamimi. Beliau lahir di kota Baghdad. Wafat pada tahun 213 H. Kuniyah belaiau adalah Abu Ahmad, Abu Ali. Nasab beliau adalah Marwazi, at-Tamimi, dan al-Baghdadi.

\section{Tabel 1. Analisa Kualitas Perawi}

\begin{tabular}{lccc}
\hline \multicolumn{1}{c}{ Nama Perawi } & $\begin{array}{c}\text { Urutan } \\
\text { Sanad }\end{array}$ & Sifat & Kualitas \\
\hline $\begin{array}{l}\text { Jariyah bin Qudamah bin } \\
\text { Zahir bin Hasin }\end{array}$ & I & Tsiqah & Diterima \\
\hline $\begin{array}{l}\text { Adl Dlahhaak bin Qais } \\
\text { bin Muawiyah bin }\end{array}$ & II & Tsiqah & Diterima \\
Hushain & & & \\
\hline $\begin{array}{l}\text { Urwah bin Zubair bin } \\
\text { Awwam bin Khawailid } \\
\text { bin As'ad bin 'Abdul Izzi }\end{array}$ & III & Tsiqah & Diterima \\
bin Qu & & & \\
\hline $\begin{array}{l}\text { Abdullah bin Dzakwan } \\
\text { Al-Farsyi }\end{array}$ & IV & Tsiqah & Diterima \\
\hline $\begin{array}{l}\text { Abdur Rahman bin } \\
\text { Abdullah bin Dzakwan }\end{array}$ & V & Tsiqah & Diterima \\
\hline $\begin{array}{l}\text { Husain bin Muhammad } \\
\text { bin Bahram bin Husain }\end{array}$ & VI & Tsiqah & Diterima \\
bin Muhammad at- & & & \\
Tamimi & & & \\
\hline
\end{tabular}

Dari Segi kualitasnya, hadis ini merupakan hadis Shahih. Dengan kriteria yaitu Rawinya Adil dan bersambung sanadnya. Hadis ini merupakan Hadis Marfu', karena hadis ini diterima langsung dari Rasulullah saw.

\section{Kajian Lughawi}

Marah atau Ghadhab (غضب) menurut al-Ghazali adalah percikan api dari api Allah yang menyala-nyala dalam sanubari manusia, ia ada dalam relung hati 
paling dalam seperti posisi bara diantara abu, yang bisa mengeluarkan ghadhab adalah keangkuhan yang terpendam dalam hati orang-orang angkuh seperti keluarnya batu yang menyala-nyala dari besi. ${ }^{16}$ Dari definisi ini, bisa dipahami alGhazali sedang menjelaskan Ghadhab dari sisi negatif. Yaitu ghadhab yang sudah berada di luar kondisi manusia. Oleh karena itu, penulis pada bagian ini akan membahas Ghadhab dalam dimensi ini, yaitu negatif. Banyak sekali hadis nabi yang berbicara tentang bahaya sifat Ghadhab.

Dalam bab Bayan Dham Al-Ghadhab, al Ghazali mengutip sebuah hadis nabi saw, yang menunjukkan bahwa manusia paling kuat bukan orang yang tidak terkalahkan namun orang yang dapat menguasai dirinya pada saat dia marah. Dalam hadis lain, Nabi saw juga mengatakan "barang siapa yang menahan amarahnya maka Allah ta'ala akan menutupi keburukannya". Dalam sebuah hadis juga disebutkan bahwa Ghadhab bisa merusak iman.

Ketika seseorang tidak bisa mencapai apa yang ia inginkan, maka api amarah menyala, darah mengalir dengan kencang ke nadi, kemudian ke otak dan ke jantung, seperti nyalanya api, seperti air yang mendidih sehingga wajah seperti tetumpahi darah dan menjadi merah, demikian juga mata dan kulit. Wajah, mata dan kulit mengisahkan apa yang terjadi di balik warna kulit itu. Secara umum menurut Al-Ghazali, amarah itu adanya di dalam hati, dan mengalir pada anggota lain.

\section{Analisa Neuropsikologis Hadis Larangan Marah}

Selain berpengaruh pada kesehatan, diantara beberapa perubahan yang terjadi ketika ada ekspresi marah terjadi. Lingga Kusuma (2018) dalam tulisannya menjelaskan bahwa sumer utama dari marah adalah munculnya hal-hal yang mengganggu aktivitas yang dapat menghambat dari tujuan individu, yang akhirnya dapat di ekspresikan dengan mengepalkan tangan dan memukul, perilaku kesal, mengamuk, dan keregangan satu sama lain. Selain perilaku tersebut, kemarahan juga bisa memunculkan ketakutan pada pelakunya, mucnulnya perasaan sedih dan khawatir. ${ }^{17}$ Selain itu Jimmy Calanchini, dkk (2016) mnejelaskan bahwa ekspresi marah menyebabkan proses yang melebar bahkan bisa menyebar kepada mereka yang sebenarnya tidak ada kaitannya dengan permasalahan yang terjadi. Ekspresi marah didefinisikan sebagai isyarat

\footnotetext{
${ }^{16}$ A. H. al-Ghazali, Ibya Ulumidin Juz 3 (Indonesia: Maktabah Dar Iya Kutub al- Arabiyah, n.d.).

${ }^{17}$ Lingga Kusuma Wardani, Dhita Kurnia Sari, “Analisa Kemampuan Mengontrol Marah Ditinjau Dari Penerapan REBT (Rational Emotive Behavior Therapy) Pada Klien Skizofrenia Di UPT Bina Laras Kras Kediri," November 2018 7, no. 2, STRADA Jurnal Ilmiah Kesehatan (2018): 57-61.
} 
kognitif antar pribadi yang berarti dapat mempengaruhi sejauh mana informasi persuasif diteliti. ${ }^{18}$

Beberapa gejala-gejala emosi marah yang juga direkam Alquran diantaranya;

Pertama, ekspresi marah yang tampak pada raut muka. Perubahan raut muka dengan ungkapan muswaddan (hitam pekat). Dalam lingua franca Indonesia, kondisi sncaman itu dibahasakan dengan istilah "merah padam".

Kedua, ekspresi marah dengan kata-kata. Marah dalam hal ini berupa kata-kata yang keluar sesuai dengan keadaan dia tersulut emosi. Biasanya berupa cacian atau kata-kata pedas yang bisa jadi diucapkan secara tidak sadar.

Ketiga, ekspresi marah dengan tindakan. Dalam keadaan marah seperti ini, biasanya lebih bersifat pelampiasa secara fisik. Misalnya saja memukul, melempar sesuatu atau menendang.

Keempat, ekspresi marah dengan diam (marah di hati). Pada orang yang mengalami ini, dia terkadang menyembunyikan amarahnya sendiri, bisa jadi melupakan kemudian atau memendam dan sampai memikirkannya. ${ }^{19}$

Selain dari Alquran, dalam ilmu psikologi juga ada beberapa ekspresi manusia ketika marah, seperti yang ditulis oleh Better Health Channel, ${ }^{20}$ bahwa ada dua kemungkinan ekspresi ketika seseorang marah, yakni:

Pertama, anger explosions atau kemarahan yang meledak. Ada sebagian orang yang ketika marah tidak memiliki kendali sehingga meledak-ledak atau mengamuk. Prilaku mengamuk dapat menyebabkan orang yang tidak mengendalikan emosi dapat mengisolasi diri dari keluarga dan teman. Tipe orang anger explosions cenderung memiliki harga diri rendah, dan menggunakan kemarahan untuk memanipulasi.

Kedua, anger repression atau kemarahan yang menekan. Pola ini berarti bahwa seseorang yang mengalami kemarahan, kemudian akan melampiaskan pada perilaku-perilaku negatif yang berbentuk pelarian. Misalnya saja dengan pergi ke pesta, melampiaskan pada anak atau peliharaan.

${ }^{18}$ Jimmy Calanchini, Wesley G. Moons, Diane M. Mackie, "Angry Expressions Induce Extensive Processing of Persuasive Appeals," 15 February 2016, Journal of Experimental Social Psychology (2016).

${ }^{19}$ M. Darwis Hude,. Ibid. Hal. 164

20 betterhealth.vic.gov.au, "Anger: How It Affect People,” Better Health Channel, n.d., https://www.betterhealth.vic.gov.au/health/healthyliving/anger-how-it-affectspeople?viewAsPdf $=$ true. 
Nasir (2013) dalam penelitiannya menyebutkan bahwa meskipun kemarahan adalah emosi yang umum dan alami, itu mengarah pada agresi dan begitu banyak konsekuensi negatif lainnya seperti pembunuhan dan kekerasan. Dengan demikian, kemarahan harus dikelola. Orangtua, guru dan konselor sekolah seharusnya bekerja sama untuk mengatur program manajemen kemarahan untuk membantu mengelola kemarahan di kalangan remaja. ${ }^{21}$

Tidak dipungkiri bahwa kemarahan memiliki dampak negatif yang sangat banyak, dan berbahaya terhadap kondisi individu bahkan masyarakat, jiwa dan raga, materi dan immateri. Selain marah berdampak pada perubahan sosial seseorang, juga dapat merubah situasi dan kondisi tubuh yang signifikan. Dalam kajian psikologi kognitif, perasaan marah dapat mempengaruhi kinerja otak dan tubuh secara terstruktur, seperti yang ditulis dalam National Institute for the Clinical Application of Behavioral Medicine $e^{22}$, yakni:

1. Percikan pertama dari Amigdala mempengaruhi kinerja amigdala bahkan sebelum orang tersebut menyadarinya.

2. Dari hal tersebut, amigdala kemudian mengaktifkan hipotalamus.

3. Hipotalamus memberikan sinyal kelenjar pituatari dengan melepaskan hormon pelepasan corticotropin (CRH).

4. Hipofisis mengaktifkan kelenjar adrenal dengan melepaskan hormon adrenocorticotropin (ACTH).

5. Kelenjar adrenal mensekresikan hormon stres seperti kortisol, adrenalin, dan nonadrenalin.

Jefferson Academic Program menuliskan sebuah studi dari beberapa masalah penyakit yang terjadi lebih dari $80 \%$ nya disebabkan oleh gangguan sosialemosional dan 16\% lainnya adalah bersifat organik (Wolf \& Goodell). Studi lain menyebutkan bahwa gejala seprti nyeri dada dan pusing yang terjadi pada 567 pasien, $84 \%$ nya tidak ditemukan diagnosa medis. ${ }^{23}$

Melihat adanya beberapa dampak yang disebabkan oleh keadaan marah, maka sebenarnya marah merupakan suatu reaksi emosional yang melibatkan

${ }^{21}$ Rohani Nasir Norisham Abd Ghani, "Behavioral and Emotional Effect of Anger Expression and Anger Management among Adolescents," no. Procedia-Social and Behavioral Scinces, PSYSOC (2013): 565-569.

${ }^{22}$ NICABM, "How Anger Affects the Brain and Body (Infographic)," n.d., accessed October 30, 2018, https://www.nicabm.com/how-anger-affects-the-brain-and-bodyinfographic/.

${ }^{23}$ Thomas Jefferson University Hospital Thomas Jefferson University, "How Emotional Processes Affect Physical Health and Well Being," Jefferson: Myrna Brind Center of Integrative Medicine (Philadelphia, n.d.). 
perubahan baik secara fisik maupun psikis. Tak hanya itu, keadaan menahun dari kemarahan juga memunculkan penyakit.

Jika dilihat dari adanya beberapa dampak dari perilaku marah, maka terdapat kesinambungan antara hadis yang dijadikan rujukan oleh penulis dengan yakni bahwa perilaku marah tersebut membawa pada dampak bukan hanya secara mental, psikologisdanneurologistetapijugaadanyakesenjangan yang akan terjadi dalam kehidupan sehari-hari. Yang kemudian hadis ini dapat dijadikan sebagai rujukan manusia dalam berperilakus ehari-hari, selain karena sebab yang tampak secara nyata pengaruh dari efek marah, Nabi saw pun memerintahkan untuk tidak marah atau emosi.Bahkan dalam hadis Nabi mengulangi perkataan untuk tidak marah sampai berkali-kali yang menunjukkan marah merupakan perilaku yang simple namun sangat dilarang dan tidak baik.

\section{Cara Menghilangkan Marah}

Perasaan marah memang tidak dapat dihilangkan karena memang merupakan sebuah naluriah. Febie Ola (2012) mneyebutkan bahwa ada korelasi yang signifikan antara asertivitas terhadap pengungkapan emosi marah. Penelitian ini menyebutkan bahwa ketika seorang remaja melakukan asertifitas maka akan semakin terkontrol dalam mengungkapkan emosi marah, begitu juga sebaliknnya. ${ }^{24}$ Ada tiga cara untuk melatih agar gadhab terkendali menurut alGhazali, bagian pertama, latihan (riadhah) bukan untuk menghilangkan amarah dalam hati akan tetapi tujuannya agar kita tidak menuruti amarah, dan tidak mengindahkan amarah kecuali hanya pada persoalan yang tidak dilarang agama dan tidak bertentangan dengan akal sehat. Latihan tahap ini bisa dilakukan dengan mujahadah dan memaksakan diri untuk mejadi orang bilim. Dan melakukannya terus menerus sampai bilim menjadi akhlak yang menancap. Menurut al-Ghazali mencabut akar gadhab berlawanan dengan naluri, bahkan menurutnya itu tidak akan mungkin bisa dilakukan. Yang mugkin dilakukan adalah memecah dan melemahkan potensinya sehingga jika bangkit maka tidak terlalu berlebihan dalam batin, dan tidak sampai bekasnya muncul di wajah.

Latihan kedua menurut al-Ghazali, adalah usaha untuk melepas gadhab, itu mungkin dilakukan, dengan merenungkan bahwa tempat terakhir manusia adalah kuburan dan sehingga ia bisa zuhud di dunia. Dalam posisi ini, seperti seseorang yang memiliki anjing tidak ia sukai tidak pula ia benci (gadhab) pada saat anjing itu dipukul. Riyadhah dalam bagian ini menghilangkan akar gadhab. Menurut al-Ghazali jarang sekali orang yang sampai pada posisi ini. Menurut al-

\footnotetext{
${ }^{24}$ Febie Ola Falentina, Alma Yulianti, "Asertivitas Terhadap Pengungkapan Emosi Marah Pada Remaja,” Juni 2012 8, no. 1, Jurnal Psikologi (2012).
} 
Ghazali salah satu latihannya dengan menyibukan hati dan pikiran dengan halhal positif, menurut al-Ghazali dalam kondisi ini gadhab tidak lagi mendapatkan tempat. Al-Ghazali mmengisahkan kisah Salman al-Farisi. Salman di caci, dan ia menjawab "Aku sedang merisaukan timbanganku kelak diakhirat, Aku lebih buruk dari cacianmu, jika timbanganku baik diakhirat maka cacianmu tidak membuatku susah. ${ }^{25}$

Dalam kajian ke-Islaman, Alqurantelah menuliskan beberapa ayat untuk mengobati atau terapis marah. Misalnya saja memberikan tindakan pemaafan ketika marah, seperti yang terdapat dalam QS.An Nahl ayat 126-127 yang artinya:"Dan jika kamu memberikan balasan, maka balaslah dengan balasan yang sama dengan siksaan yang ditimpakan kepadamu. Akan tetapi jika kamu bersabar, sesungguhnya itulah yang lebih baik bagi orang-orang yang dralim" (An-Nahl: 126-127)

Terlepas dari kajian spiritualitas ke-Islam-an, ada cara untuk meredam rasa marah dalam aspek psikologis, seperti yang ditulis oleh Michael W.

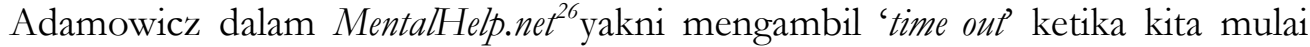
marah, atau sementara waktu menghindar atau menyingkir dari situasi yang bisa memancing kemarahan untuk menenangkan diri. Selain itu, bisa juga dilakukan dengan mengalihkan pembicaraan dari hal-hal yang mengganggu mood kepada topik-topik yang lebih netral. Tetapi pada dasarnya setiap orang mempunyai cara terbaik untuk menghindar dari sifat marah, sebab hanya orang itu sendiri lah yang lebih mengenal dirinya.

Lebih detail lagi dijelaskan oleh Mayo Clinic Staff mengenai 10 cara memenejemen marah, yang bisa dilakukan untuk menghindarinya, yakni sebagai berikut: ${ }^{27}$

1. Think before youspeak atau berpikir dahulu sebelum berbicara. Jelas ini merupakan salah satu cara untuk menghindari diri atau orang lain untuk memancing rasa marah yang sangat sepele tetapi justru diabaikan setiap individu.

2. Once You're Calm, Express Your Anger atau Setelah Anda tenang, ekspresikan kemarahan Anda. Marah bukan berarti benar-benar tidak boleh, melainkan perasaan itu dapat di ekspresikan sebaik mungkin, tanpa menyakiti siapapun dan disampaikan dengan tegas teteapi tidak menyinggung.

${ }^{25} \mathrm{Al}-$ Ghazali, Ibya Ulumidin Juz 3, 167.

${ }^{26}$ Licsw Michael W. Adamowicz, “Anger Diary and Triggers,” Mental Help.Net (American Addiction Centers, n.d.).

${ }^{27}$ Mayo Clinic Staff, “Anger Management: 10 Tips to Tame Your Temper," Healthy Lifestyle Adult Health, Mayo Clinic, n.d. 
3. Get Some Exercise atau melalui beberapa tahapan pelatihan. Dapatkan kegiatan di luar ruangan yang bisa menghilangkan kemarahan anda, misalnya bisa dengan berlari, jalan-jalan sore atau lakukan hobi yang kita senangi.

4. Take a timeout atau mengambil waktu tunggu. Terlebih bagi orang dewasa, kecenderungan untuk stres dan marah lebih besar dibandingkan anak-anak. Oleh karenanya waktu istirahat juga perlu dilakukan terlebih ketika perasaan sudah tidak nyaman dan marah.

5. Identify Possible Solution atau mengidentifikasi solusi yang memungkinkan dilakukan. Ketika marah tak selamanya seluruh perasaan menjadi tak terkendali. Ada sisi dimana kita juga bisa memikirkan hal lain mengenai sebuah solusi atau problem solving yang bisa kita lakukan dari pada kita marah-marah.

6. Stick with ' $I$ ' statements atau gunakan pernyataan "saya". Maksudnya adalah ketika terjadi satu perdebatan yang memicu kemarahan, biasanya kata-kata yang keluar pun bisa hal-hal yang buruk. Dalam hal ini penggunaan kata "saya" dalam mengajukan argumen setidaknya akan sedikit meredakan kemarahan sebab "saya" mengarah pada sikap merendah.

7. Don't hold a grudge atau jangan menyimpan dendam. Ketika kita sudah membenci seseorang atau suatu hal, secara tidak langsung kita sudah menyimpan dendam amarah. Oleh karenanya ketika kita bersinggungan dengan hal tersebut, perasaan marah akan otomatis muncul.

8. Use bumor to release tension atau Gunakan humor untuk melepaskan ketegangan. Keringanan dapat membantu meredakan ketegangan. Gunakan humor untuk membantu Anda menghadapi apa yang membuat Anda marah dan, mungkin, harapan yang tidak realistis yang Anda miliki tentang bagaimana hal-hal harus dilakukan. Hindari sarkasme, meskipun - itu dapat menyakiti perasaan dan membuat segalanya lebih buruk.

9. Practice relaxation skills atau berlatih ketrampilan relaksasi. Ketika amarah Anda menyala, lakukan proses relaksasi untuk membantu meredam amarah. Berlatih latihan pernapasan dalam, bayangkan adegan santai, atau ulangi kata atau frasa yang menenangkan, seperti "Tenang saja." Atau bisa juga dengan mendengarkan musik, menulis di jurnal atau melakukan beberapa pose yoga - apa pun yang diperlukan untuk mendorong relaksasi.

10. Know when to seek help atau mengetahui kapan harus mencari bantuan. Belajar mengendalikan amarah memang merupakan sebuah tantangan yang cukup 
berat. Oleh karenanya mintalah pertolongan orang disekitar anda untuk membantu anda melupakan emosi atau setidaknya untuk meminimalisir kemarahan anda, sebelum anda akhirnya melampiaskannya dengan hal-hal yang negatif.

\section{Kesimpulan}

Pada hadis tentang larangan marah ini memiliki sanad perawi yang langsung tersambung sampai ke Rasulullah Saw. dan hadis tersebut termasuk dalam kategori hadis Marfu'. Relevanasi dalam sisi neuropsikologi, sangat jelas terlihat banyak sekali efek yang ditimbulkan jika seseorang melakukan marah, misalnya saja akan berdampak pada menegangnya saraf-saraf tubuh, bergejolaknya darah dan kecenderungan otak yang tidak stabil.

Perilaku marah bukan hanya diekspresikan dengan meningginya tensi psikologis dari seseorang, tetapi juga pada munculnya perilaku negatif seperti mengekspresikannya pada penekanan terhadap satu hal yang berbahaya. Bisa dilihat baik dari segi psikis yang tertekan maupun dari segi sosial. Misalnya mulai dari melakukan tindakan secara fisik bahkan menjauhkan dari fungsi sosial. Marah memang tidak bisa 100\% dihilangkan dari manusia karena sudah menjadi bagian dari naluriah, akan tetapi baik secara psikologis maupun secara spiritual perilaku tersebut dapat di minimalisir atau di tekan lagi dengan cara berbeda pada masing-masing individu. Dari intervensi yang bisa kita ambil dalam penelitian ini dalam aspek Islam yakni bahwa hadis ini bisa dijadikan sebagai terapi atau penyeimbang dalam kehidupan sehari-hari pada khususnya dalam keadaan marah, yang kemudian dapat disampaikan melalui mimbar-mimbar dakwah terlebih hadis ini termasuk kedalam hadis shahih sehingga bisa menjadi dasar hukum (referensi hadis).

\section{Bibliografi}

A. H. al-Ghazali. Ibya Ulumidin Juz 3. Indonesia: Maktabah Dar Iya Kutub alArabiyah, n.d.

A. Qarni. Laa Taghdhab (Jangan Marah). Jakarta: Al-Qalam, 2013.

Al-Ghazali. Ibya Ulumidin Juz 3. Indonesia: Maktabah Dar Iya Kutub alArabiyah, n.d.

betterhealth.vic.gov.au. "Anger: How It Affect People.” Better Health Channel, n.d. https://www.betterhealth.vic.gov.au/health/healthyliving/angerhow-it-affects-people?viewAsPdf=true.

Febie Ola Falentina, Alma Yulianti. "Asertivitas Terhadap Pengungkapan Emosi Marah Pada Remaja.” Juni 2012 8, no. 1. Jurnal Psikologi (2012). 
Jimmy Calanchini, Wesley G. Moons, Diane M. Mackie. "Angry Expressions Induce Extensive Processing of Persuasive Appeals.” 15 February 2016. Journal of Experimental Social Psychology (2016).

Lingga Kusuma Wardani, Dhita Kurnia Sari. “Analisa Kemampuan Mengontrol Marah Ditinjau Dari Penerapan REBT (Rational Emotive Behavior Therapy) Pada Klien Skizofrenia Di UPT Bina Laras Kras Kediri." November 2018 7, no. 2. STRADA Jurnal Ilmiah Kesehatan (2018): 5761.

M. Asy-Syahawi. Saat-Saat Rasulullah Marah. Jakarta: Pustaka Azzam, 2005.

M. Darwis Hude. Emosi. Jakarta: Penerbit Erlangga, 2006.

Mayo Clinic Staff. "Anger Management: 10 Tips to Tame Your Temper." Healthy Lifestyle Adult Health. Mayo Clinic, n.d.

Michael W. Adamowicz, Licsw. "Anger Diary and Triggers." Mental Help.Net. American Addiction Centers, n.d.

Moch. Sya'roni Hasan. "Manajemen Marah Dan Urgensinya Dalam Pendidikan" 1 No.2. Al-Idaroh (September 2017).

Nandhini H. Anggarasari, Fuad Nashori, RA Retno Kumolohadi. "Terapi Tawa Untuk Mengurangi Emosi Marah Pada Caregiver Lansia” 6, No. 1. Jurnal Intervensi Psikologi (2014).

NICABM. "How Anger Affects the Brain and Body (Infographic)," n.d. Accessed October 30, 2018. https://www.nicabm.com/how-angeraffects-the-brain-and-body-infographic/.

Norisham Abd Ghani, Rohani Nasir. "Behavioral and Emotional Effect of Anger Expression and Anger Management among Adolescents," no. Procedia-Social and Behavioral Scinces. PSYSOC (2013): 565-569.

Rita Susanti, dkk. "Perasaan Marah Membuat Terluka" 10 No.2. Jurnal Psikologi (December 2014).

S. M. Edward E. Smit. Psikologi Kognitif: Pikiran Dan Otak. Yogyakarta: Pustaka Pelajar, 2014.

S. M Lari. Psikologi Islam. Bandung: Pustaka Hidayah, 1995.

Safiruddin Al- Baqi. "Ekspresi Emosi Marah" 23, no. Fakultas Psikologi Universitas Gadjah Mada. Buletin Psikologi (June 2015).

Suryadi, Muhammad Alfatih Suryadilaga. Metodologi Penelitian Hadis. Yogyakarta: TH Press, 2012. 
96 | AL QUDS : Jurnal Studi Alquran dan Hadis vol. 3, no 1, 2019

Thomas Jefferson University, Thomas Jefferson University Hospital. "How Emotional Processes Affect Physical Health and Well Being." Jefferson: Myrna Brind Center of Integrative Medicine. Philadelphia, n.d.

Widya Citra A. "4 Hal Yang Bisa Jadi Penyebab Anda Mudah Marah Sepanjang Hari," n.d. https://hellosehat.com/hidup-sehat/psikologi/4-penyebabmudah-marah/.

Aplikasi Hadis. Jawami’ Al-Kalim, n.d. 